\title{
AMERICAN STATUTORY MODIFICATIONS OF THE RULE AGAINST PERPETUITIES, OF TRUSTS FOR ACCUMU- LATION AND OF SPENDTHRIFT TRUSTS
}

\section{LOUIS Barcroft RunK $\dagger$}

The so-called rule against perpetuities had its origin in a decision by Lord Chancellor Nottingham in $168 \mathrm{r}, 1$ and while originally judge-made law, is now universally recognized as part of the common law. Closely related to this rule, but purely statutory, are trusts for accumulation, the duration of which under some statutes is limited to a shorter period than that prescribed by the rule against perpetuities. The so-called "spendthrift trust" is an American exotic with only a century of growth behind it.

As the original forms of all of these have been modified in many states by recent legislation, the purpose of this article is to briefly summarize these statutory changes down to date, subject to the limitations of the average indices to the Pamphlet Laws issued since the latest editions of compiled or annotated statutes in the various states, and then to surmise the underlying causes that led to their enactment.

\section{The Rule Against Perpetuities}

In the following twenty-three states there are either no statutes or code provisions, or they recite in substance the common law rule as laid down in the Duke of Norfolk's Case and in the cases that shortly followed: Colorado, Connecticut, Delaware, Florida, Illinois, Kansas, Maine, Maryland, Massachusetts, Missouri, Nebraska, New Hampshire, New Jersey, Oregon, Pennsylvania, ${ }^{2}$ Rhode Island, South Carolina, Utah, Vermont, Virginia, Washington, West Virginia, and Wyoming. And the District of Columbia may be added to this list, as its code recites the common law rule. Georgia, Iowa and Kentucky passed statutes. intended to declare the common law, but their language is not at all clear. ${ }^{3}$

†A. B., I893, M.A., I903, Yale University; LL. B., I896, University of Pennsylvania; author of Differing Federal and State Interpretations of the Transfer Inheritance Tax Applied to Trusts Inter Vivos (1930) 79 U. OF PA. L. REv. 185.

${ }^{2}$ Duke of Norfolk's Case, 3 Cas. Ch. I, 2 Swanst. *454 (I8I8); Perre, Trusts (7th ed. I929) $\$ \S 379-80$.

In Pennsylvania in the I93I session of the Legislature, a bill was introduced providing that, for estates or interests created after its taking effect, "no estate or interest in real or personal property created by any deed, will or other instrument in writing subject to a condition precedent before it shall finally vest, shall be legal and valid unless the length of time elapsing between the commencement of the estate or interest and its final vesting is limited strictly to the period of a life in being at its commencement and one year thereafter. Any limitation beyond such period shall be deemed a perpetuity and shall be void." (H. B. 892) ; but it died in the Committee on Judiciary General to which it had been referred. See also Lawrence Est., I36 Pa. 354, 20 At1. 52I (I890) and Gerber's Est., I96 Pa. 366, 46 Atl. 497 (1900).

${ }^{3}$ GA. ANn. Code (Michie, I926) §3678; IOWA Cóbe (I927) § IOI27; Ky. STAT. (Carroll, r922) §2360. See Gray, The Rule Against Perpetuities (3d ed. I915) §§ 735-737. 
On the other hand, "perpetuities" are forbidden by the constitutions of Arkansas, North Carolina, Tennessee and Texas, ${ }^{4}$ but their courts define "perpetuities" by the common law rule. ${ }^{5}$ The constitution of Nevada ${ }^{6}$ permits them only "for eleemosynary purposes". Louisiana's constitution 7 permits its legislature to "authorize the creation of trust estates for a period not exceeding ten years after the death of the donor; provided, that where a natural person is the direct beneficiary said period may be made to extend until ten years after his majority" ; excepting, however, from the operation of this provision, donations for educational, charitable or religious purposes; but no statute has yet been passed.

Of the remaining sixteen states, Idaho, Indiana, Montana, North Dakota, Oklahoma, and South Dakota limit vested estates, in language almost identical, to "the continuance of the lives of the persons in being at the creation of the limitation or condition"; 8 while New Mexico ${ }^{9}$ provides that "whenever a conveyance or bequest is made wherein the conveyor or testator shall hold possession of propertv, be it lands or tenements, . . . each one of said conveyances or bequests shall only invest the conveyors or testators with possession during their lifetıme, . . . and at the death of said conveyor or testator said lands and tenements shall descend to the children. . . . to be equally divided among them as absolute tenants in common". California ${ }^{10}$ restricts them to "the continuance of the life of persons in being at creation of the condition; or for a period not to exceed twenty-five years from the time of creation of the suspension"; Wisconsin, ${ }^{11}$ to "continuance of a life or lives in being at the creation of the estate and thirty years thereafter"; Ohio, ${ }^{12}$ to "such person or persons . . . as are in being or to the immediate issue or descendants of such as are in being at the time of making such deed or will." New York's rule ${ }^{13}$ has long been for "two lives in being", and an act passed by the 193I session of the New York legislature to change their rule to accord with the common law rule was vetoed by the governor. Arizona ${ }^{14}$ prescribes "the continuance of two lives in being at

'ARK. Const. art. 2, § 19; N. C. Const., art. I, §31; Tenn. Const., art. I, § 22; Tex. Const., art. I, $\$ 26$.

Moore v. Moore, 59 N. C. I32 (I860) ; Munger v. Munger, 298 S. W. 470 (Tex. Civ. App. I927) ; Eager v. McCoy, I43 Tenn. 693, 228 S. W. 709 (I920).

Art. 15, \$ 4 ; Nev. CoMp. Laws (Hillyer, I929) \$372.

7 Adopted I92I, art. iv, § I6. See GRAY, op. cit. supra note $3, \$ \S 766-772$.

8 IDAHo CoMp. Stat. (IgI9) §§ 5335, 5340-5342; IND. ANN. Stat. (Burns, I926) § 13416; Mont. Rev. Codes (Choate, I921) $\$ \$ 6705,6706,6734,6736 ; N$. D. Comp. Laws AnN. (1913) \$\$ 5287-5289, 5315; OKLA. Comp. Stat. ANN. (Supp. 1926) \$\$ 8410-8413; S.

D. REV. CODE (1919) $\$ \$ 294-295,320-322,324$.

${ }^{\circ}$ N. M. Stat. ANN. (1929) \$\$117.107, II 4 .

${ }^{10}$ CAL. CIV. CODE (Deering, Ig23) \&\$715, 770, 772.

11 WIS. STAT. (I929) $\$ \$ 230.15,230.16$.

${ }^{13}$ OHIO ANN. CODE (Throckmorton, 1930) \$8622.

${ }^{13}$ N. Y. Cons. Laws (Cahill, I930) ; REAL Property Law (Ig09) \$ 42.3; McKINNEY, Cons. Laws, vol. 49; Personal Property LaW (1909) §II; MCKinNey, Cons. Laws. vol. 40. See also In re Wilcox, I94 N. Y. 288, 87 N. E. 497 (I909). The statutory provisions are quite involved and have produced much litigation.

it ARIz. REv. CoDE (Struckmyer, I928) § 2761. 
the creation of the estate and twenty-one years thereafter". Four states limit such trusts to real estate only, viz., Michigan and Minnesota, to "two lives in being at the creation of the trust"; Mississippi, to "a succession of donees, then living and upon the death of the last of said successors, to any person or any heir"; and Alabama "to the wife and children or children only . . .", and to "the heirs of the body of the survivor, if they come of age, and in default thereof, over", but to others than these then not "beyond three lives in being at the date of the conveyance and ten years thereafter." 15

In certain of these states, viz., Arizona, California, Idaho, Indiana, Michigan, Minnesota, Montana, New York, North Dakota, Oklahoma, South Dakota and Wisconsin, there are also special provisions that a contingent remainder in fee can follow a prior remainder in fee, providing that it takes effect in the event of the party having the first remainder dying under the age of twenty-one, the exact language of these statutes being found in the numbered sections of the laws of these states above cited.

It is interesting to note that in seventeen of the forty-eight states, more than one-third, the old common law against perpetuities has been changed in some way.

\section{Accumulations}

In England, the Law of Property Act of 1925 has re-enacted substantially similar provisions as were in the old Thelluson Act, ${ }^{16}$ which was never part of the common law but served as a partial foundation for the slightly varying statutes in the fourteen states which have express statutes or constitutional provisions on this subject. These accumulations are limited as follows: in Alabama, for ten years or during a minority $;^{17}$ in Arizona and Wisconsin, ${ }^{18}$ for real estate during a minority, or for twenty-one years if for certain defined charities; in California, ${ }^{19}$ the same as their statutory rule against perpetuities; in Illinois, ${ }^{20}$ during the lives of the grantor or settlor or for twenty-one years after the death of a settlor or testator, or during a minority; in Michigan and Minnesota, ${ }^{21}$ as to real estate only during a minority, the statute not applying to personalty where the rule against perpetuities is held to govern; Pennsylvania's rule is "the life or lives of any

\footnotetext{
"Mich. CoMp. Laws (Cahill, I915) \$§ II533, II534; Miss. Code of 1930, §2117; AIA. Civ. Code (Ig28) §6922; MINN. Stat. (Mason, I927) §§ 8045, \$046.

As to personalty, the common law rule would govern in all four states.

${ }^{\circ}$ Accumueations Act, 39 \& 40 Gro. III, c. 98 (I900), 22 Halsbury, The Laws of England, 370. See Perry, op. cit. sutpra note $\mathrm{I}$, at 394-395.

${ }^{17}$ ALA. CODE (1928) §6914.

${ }^{13}$ Ariz. Rev. Code (I928) § 2773; Wis. Stat. (1929) § 230.37.

${ }^{10}$ Cal. Stat. and Amend. to Codes (I929) c. I43.

30.2 SMItrh-Hurd ANN. Stat. (I930) c. 30, § I53.

${ }^{2}$ Mich. Comp. LAws (Cahill, I9I5) $\S$ II555, II556; Toms v. Williams, 4I Mich. 552,
} .2 N. W. 8I4 (I879) ; MINn. STat. (Mason, I927) \$\$ 8066, 8067; Congdon v. Congdon, I6o Minn. 343, 200 N. W. 76 (1924). 
such grantor or grantors, settlor or settlors, or testator, and the term of twenty-one years from the death of any such grantor, settlor, or testator, that is to say, only after such decease during the minority or respective minorities with allowance for the period of gestation of any person or persons, who, under the uses or trusts of the deed, will, or other assurance directing such accumulation, would, for the time being, if of full age, be entitled unto the rents, issues, interests, and profits so directed to accumulate" . . . and the courts have applied the term of twenty-one years to all estates which are not measured in terms of lives. ${ }^{22}$

Montana and North and South Dakota provide, in language substantially identical, that if the accumulation be directed to commence from the date of the instrument or the death of the person executing the same, it may be for the benefit of minors then in being or in being at such death, and to terminate at the expiration of their minority . . . ; but if it commence at any period subsequent to the death of the person executing such instrument, it may be within the time allowed for the suspension of ownership and at some time during the minority of the person for whose benefit it is intended, and must terminate at the expiration of their minority. ${ }^{23}$ Michigan and Minnesota have a clause substantially identical with this except that it is limited to rents and profits, ${ }^{24}$ but Indiana's similar statute applies only to personalty. ${ }^{25} \mathrm{New}$ York limits accumulations for the period of minority, except for certain classes of charities defined by the Acts. ${ }^{26}$ Louisiana's constitution ${ }^{27}$ might also govern accumulations.

The remaining thi-ty-four states and the District of Columbia have no statutory provision on this subject, but the rule against perpetuities has been held to govern automatically in at least three of them, ${ }^{28}$. and will probably be held applicable by the others if the direct question arises.

\section{Trusts for Public Charities as Related to Perpetuities and Accumulations}

Such trusts are free from the operation of the rule against perpetuities for both real and personal property, either by statute or by constitutional provision, in the ten states of Connecticut, Louisiana, Maryland, Michigan, Minnesota; Nevada, North Carolina, Pennsylvania, South Carolina and

${ }^{2}$ PA. StAT. (West, 1920) 18868, Act Apr. I8, 1853, P. L. 503, §9. Also see Barton v. Thaw, 246 Pa. 348, 92 Atl. 312 (I9I4) and Lilley's Est., 272 Pa. I43, II6 At1. 392 (1922).

${ }_{2}^{2}$ Mont. Rev. Cones (Choate, Ig2I) §67II ; N. D. Comp. Laws ANN. (I913) §§ 5292, 5293 ; S. D. REv. CODE (I929) \$§ 297-300.

24 Supra note 2I.

${ }^{25}$ IND. ANn. Stat. (Burns, I926) § I2I72.

${ }^{2} \mathrm{~N}$. Y. CoNs. LAws (Cahill, I930), Real Property LAw, $\S 6 \mathrm{I}$, as amended by N. Y. Laws I9I5, c. 670; Personal Property LAWS, § 16, as similarly amended, and also amended by N. Y. Laws 1927, c. 384, 68I ; N. Y. Laws 1928, c. I72.

${ }^{2}$ Supra note 7 .

${ }^{23}$ Wilson v. Di Atro, 109 Conn. 563, 145 Atl. 16I (1929); Andrews v. Lincoln, $95 \mathrm{Me}$. 54I, 50 At1. 898 (Ig0I); Helme's Est., 95 N. J. Eq. 197, I23 Ảt1. 43 (I923). 
Tennessee, and also in the District of Columbia, ${ }^{29}$ and in Massachusetts by judicial decision as to personalty, and later by statutory implication as to realty. ${ }^{30}$ Also, in Arizona and Wisconsin, for certain literary or charitable corporations of their respective states. ${ }^{31}$

They have also been declared beyond the purview of the rule by judicial decisions in fifteen other states, since, as they are not for personal or family aggrandizement, the reason for the rule ceases. These fifteen states are: Delaware, Georgia, Indiana, Iowa, Kansas, Missouri, Nevada, New Hampshire, New Jersey, New York, Oregon, Rhode Island, Vermont, Washington and West Virginia. ${ }^{32}$ Mississippi, however, prohibits all direct or indirect charitable devises and all direct charitable bequests, but trusts to others for their use are valid as to personalty, although void as to realty. ${ }^{33}$

With respect to accumulations for a public charity, Pennsylvania permits them "for any literary, scientific, charitable or religious purpose", subject to legal restrictions upon their income and the application of the doctrine of $c y$ pres, which has been frequently applied. ${ }^{34}$ In Arizona and Wisconsin ${ }^{35}$ they are permitted for twenty-one years for certain corporations of these

${ }^{2}$ Conn. Gen. Stat. (Rev. I930) §5000; Louisiana, stipra note 7; Md. Ann. Code (Bagby, I924) art. 93, $\$ 330$, as to contingent remainders, and generally by Md. Laws (193I) c. 453; Mrch. CoMp. Laws (Cahill, I915) § II099; Minn. Stat. (Mason, r927) § 8092; Nev. Const. § I65; N. C. Cum. Stat. (Michie, I925) c. 264 ; Pa. Stat. (West, I920) \$ 2590, Act of May 23, I895, P. L. II4 $\$$ I. As to accumulations for charity, see PA. STAT. (West, 1920) § 2596, Act of Apr. 26, 1855, P. L. 328 § 12; S. C. Acts 1925, No. 37, p. 6I; Tenn. Code I932, § 9593; D. C. Acts of I930, p. 356, \& 312 .

= Jackson v. Phillips, 96 Mass. 539 (I867) ; Mass. Gen. Laws (Ig2I) c. I84, § 23 ; cf. Flynn v. Caplan, 234 Mass. 516, I26 N. E. 776 (1920). For the management and accumulation for one hundred years by the City of Boston of the Benjamin Franklin Fund, part of which, now $\$ 476,038$, is to accumulate for a second hundred years, see City of Boston $v$. Members of Franklin Foundation, I77 N. E. 557 (Mass. I93I).

${ }^{31}$ Ariz. Rev. Code (Struckmyer, 1928) \$ 276r ; Lowell v. Lowell, 29 Ariz. 138, 240 Pac. 280 (I925); WIS. STAT. (I929) \$230.15, following the decision of Danforth v. City of Oshkosh, IIg Wis. 262,97 N. W. 258 (I903).

${ }^{32}$ State v. Griffith, 2 Del. Chanc. 392 (I847); Cumming v. Trustees, 64 Ga. I05 (I879); Richmond v. Davis, ro3 Ind. 449,3 N. E. 130 (1885); Phillips v. Harrow, 93 Iowa 92, 6I IN. W. 434 (I894); Wilson v. Bank, 164 Iowa 402, I45 N. W. 948 (1914); Troutman v. DeBoissiere, 66 Kan. I, 7 I Pac. 286 (I903), 64 Pac. 33 (I90I); Bank v. Robinson, 96 Mo. App. 385, 70 S. W. 372 (1902) ; Buchanan v. Kennard, 234 Mo. II7, I36 S. W. 415 (I9II); In re Hartung, 40 Nev. 262, I60 Pac. 782 (IgI6); Rolf v. Lefebre, 69 N. H. 238, 45 Atl. ro87 (1897); Hilliard v. Parker, 76 N. J. Eq. 447, 74 Atl. 447 (1909); Davidge's Will, 200 App. Div. 437, I93 N. Y. Supp. 245 (1922); Brown v. Brown, 7 Ore. 285 (1879); Mason v. Perry, 22 R. I. 475, 48 Atl. 67I (I90I); Rhade Island Trust Company Y. Warwick, 29 R. I. 393, 7I Atl. 644 (I909); Clement y. Hyde, 50 Vt. 7 I6 (I878); Galland's Est., I03 Wash. I06, I73 Pac. 740 (I9I8) ; Mercantile Bank v. Showacre, I02 W. Va. 260, I35 S. E. 9 (1926). The remaining states where, so far as searches show, the question has not directly arisen, would probably follow the same course.

${ }^{33}$ Mrss. COdE (I930) $\$ \$ 3564,3565$; Blackbourn v. Tucker, 72 Miss. 735, I7 So. 737 (I895); Hailey v. McLaurin's Est., II2 Miss. 705, 73 So. 727 (I916).

" PA. Stat. (West, 1920) \$2590, Act of May 23, I895. P. L. II4, § I; PA. STAт. \$ 2593, Act of May 26. 1876, P. L. 21 I, \$ I; PA. STAT. \$ 2.596, Act of Apr. 26, r855, P. L. 328, \$\$ 4, I2; PA. Stat. \$ 2606, Act of Apr. 22, 1889, P. L. 42, \& 1, and Act of Apr. I8, I929, P. L. 539 . See also Burns' Est., 69 PITTS. LEG. J. 24I (O. C. Alleg. County 19r9) and cases therein cited; 2 Pepper \& Lewis DrG. Dec. 2800 and supplements.

${ }^{25}$ Artz. Rev. Code (Struckmyer I928) § 2773; WIS. Stat. (I929) § 230.37. 
respective states. New York $^{36}$ and Louisiana ${ }^{37}$ have been previously mentioned. Alabama's ten-year rule ${ }^{38}$ would probably apply.

As to the remaining states, there are no statutes against accumulations for public charities so far as searches show, and in those states where the courts have held the rule against perpetuities not to apply to a public charity, since the English Accumulations Act is not part of our common law, we have no restrictions at all on such accumulations ${ }^{39}$ except in so far as the courts can hold any trust void for remoteness, ${ }^{40}$ or, in so far as a court of equity may limit the period of accumulations where, in its judgment, a sound public policy demands that the period prescribed by the donor should be shortened.

Regarding this doctrine, Professor Gray remarks, "The objection to allowing a charitable fund to accumulate is an objection of public policy, and it would seem better that the matter should be fixed by a positive rule of law than left to the discretion of judges. The discretion which chancellors exercise is a discretion in arranging the claims of one individual against another, not in setting limits to the operation of rules of public policy. It is a novel head of equity." 41 While this is entirely true, the same criticism might equally well have been made of the Rule Against Perpetuities when it was first enunciated in I68I. Cases like these, however, are infrequent, since, if the beneficial interest is immediately vested in the charity and only the possession postponed, no question as to a perpetuity arises. ${ }^{42}$ Various other statutory restrictions on charitable gifts by will could be mentioned. ${ }^{43}$

${ }^{30}$ Supra note 26.

3 Supra note 7.

${ }^{3}$ Supra note I7.

${ }^{39} 2$ Perry, op. cit. supra note $\mathrm{I}$, at $\$ 738$; Woodruff v. Marsh, 63.Conn. 125, 26 At1. 846 (1893) ; Ingraham v. Ingraham, 169 I11. 432,48 N. E. $56 \mathrm{I}, 49$ N. E. 320 (1897) ; Burn's Est., supra note 34.

${ }^{* 0}$ Girard Trust Co. v. Russell, I79 Fed. 446 (C. C. A. 3d, I9Io). See also St. Paul's Ch. v. Attorney General, I64 Mass. I88, 4I N. E. 23I (I895); Norton v. Oldfield, 219 Mass. 374, I06 N. E. Ior $_{4}$ (I9I4), and Oldfield v. Attorney General, 219 Mass. 378, 106 N. E. I015 (I9I4).

${ }^{4} \dot{\mathrm{G}}_{\mathrm{RAY}}$ op. cit. supra note 3, $\S \S 679 \mathrm{a}$ and 607 ; Tincher v. Arnold, I47 Fed. 665 (C. C. A. 7 th, I905) 7 L. R. A. (N. S.) 47 I (I907); Reasoner v. Herman, I9I Ind. 642, I34 N. E. 276 (I922).

2 Ibid.

${ }^{3}$ These interesting prerequisites to the validity of charitable gifts, but not strictly germane to this article are: California, will executed 30 days before death and not to give more than one-third of the estate, if there are legal heirs (CAL. Crv. CODE (Deering, I923) \$ I3I3, as amended Cal. Stat. AND AMEND. To Codes (I93I) c. 28I, \$ 4I) ; District of Columbia, one calendar month before death (D. C. CODE (I930) 4I8, \$ 42); Georgia, 90 days before death and not over one-third if there is a wife or issue (GA. ANN. CODE (Michie, I926) $\$ 385 \mathrm{I}$ ); Idaho, like Georgia, except 30 days and the wife is not mentioned (IDAHo Comp. STAT. (I9I9) \$7833); Iowa, not over one-fourth can be given to charity if a spouse, issue or parent survive (IOWA CODE (I927) § II848); Louisiana, the disposable portion by will or a donation mortis causa, as the statute terms it, aepends on the number of children or descendents, varying from one-third to two-thirds (LA. REv. Cry. CoDE (Merrick's 3d ed. I925) art. I493); Maryland, will must direct a special corporation to be formed in twelve months from its probate (MD. ANN. CoDE (Bagby, I924) art. 93, § 337); Montana, will executed 30 days before death unless less than one-third of the estate is given (MONT. REv. CoDEs (Choate, 1921) § 70I5); New York, valid up to one-half of the estate, if the spouse, 
What has caused this flood of statutory changes in the so-called Rule Against Perpetuities and Trusts for Accumulations? Probably the same fundamental reason that caused the original decision in the Duke of Norfolk's Case, ${ }^{44}$ and also the original enactment of the Thelluson Act, ${ }^{45}$ namely, the ccnstantly recurring desire in successive generations of those owning property to tie up its final disposition as far as possible, and the contrary feeling of the majority of the legislators that in the public interest this inclination should be curbed. As to the restraints on accumulations, a California court said : ${ }^{40}$

"The prohibition . . . was made to prevent an unfeeling and selfish testator from so devising his estate as to make persons rich in the distant future, to the detriment of those during the period of limitation who had better claims on his bounty. The latter had to live in poverty in order that their children or grandchildren might be made rich at a distant future day."

In many cases this tendency to tie up estates is due to a desire on the part of the settlor or testator to preserve his memory as long as possible. Most people rebel inwardly against the prompt oblivion that so quickly blots out any lasting memory of the lives of the vast majority of their fellows. A great many public charitable foundations have as one of their creative motives this desire to be somehow or somewhere. remembered in the next generation. But such devises or bequests, being presumed to be for the public good, are generally exempted from the Rule against Perpetuities, or, in some states, are allowed to accumulate for a limited period.

In most cases, however-and this applies also to the "spendthrift trusts" that will be considered later-the testator or settlor is unwilling to give his children the full enjoyment of all the bounty he has stored up. He has seen them grow up before his eyes from helpless babyhood, and canriot imagine them fully capable of holding what he has acquired, so he puts his property in trust for the entire period of their lives in order that it will still be intact at their respective deaths. He is unwilling to trust his own children, even when they are of mature.age, and in his blindness envisages the grandchildren or great-grandchildren whom, in all probability, he will never see, as being a group of supermen or superwomen who can be trusted much better. $\mathrm{He}$ refuses to look all. the facts in the face and will not force home to his con-

child, descendent or parent survive (N. Y. Cons. LAws (Cahill, 1930) Decedent Estate LAw § I7, as amended by N. Y. Laws 1923, c. 301; N. Y. Laws 1927, c. 502; N. Y. Laws I929, c. 229, § 3) ; Ohio, will must be executed one year before death (OHIo ANN. CoDE (Throckmorton, 1930) § 10504); Pennsylvania, will executed 30 days before death and attested by two credible and at the time disinterested witnesses (PA. STAT. (West, I920) \$ 8312 , Act of June 7 , 1917, P. L. $403, \S 6$ ).

"Supra note I.

4S Supra note 16.

${ }^{40}$ Goldtree v. Thompson, 79 Cal. 6r3, 624, 22 Pac. 50, 53 (I889). 
sciousness the fact that under these rules against perpetuities and against accumulations a group will ultimately come into existence and take when they are of age the bulk of the property left in trust. The family moneymaker, who has graduated from the "university of hard knocks" (if the expression may be pardoned), has the persistent feeling that his efforts to save his children from some of the hardships he has experienced have in many ways unfitted them for life as it must be lived, and have developed in his children a philosophy of regarding their padded existences mainly as a "chance for self-indulgence". We are the products of our heredity and our environment, with the latter largely predominating, and if, with his influence and example constantly before them, the settlor's or testator's own children are not to be trusted, how much less capable and less trustworthy are the unborn grandchildren or great-grandchildren likely to be, whose upbringing may be even more indulgent than that of their parents, and who, when they receive their patrimony at twenty-one, are much more likely to squander it than their parents would be had it been gradually placed in their hands,--part of it at thirty, part at forty, and the balance, say, at fifty years of age? It may take great tact to impress this viewpoint on would-be settlors or testators, but if it is a correct one it should at least be tried. This principle, if carried out in practice, might mean trusts of shorter duration, but it would mean a greater number of trusts, in order to secure careful investment and constant supervision of the corpus.

\section{Spendthrift Trusts}

The ancestral home of the spendthrift trust is in Pennsylvania. Its chief characteristic is a proviso that the equitable title of the cestui que trust cannot be taken away by any involuntary alienation. The title, though well established in usage, is unfortunate. One unversed in modern legal terminology might momentarily think that a spendthrift trust was a trust for a spendthrift, who is defined by statute in Massachusetts to mean "a person who is liable to be put under guardianship on account of excessive drinking, gaming, idleness or debauchery." 47 The definitions in some other states are substantially similar, and there is sufficient confusion for an Illinois court to recently explain the difference. ${ }^{48}$ The average beneficiary, however, of a modern spendthrift trust is generally a respectable and much esteemed member of society who would be deeply incensed at having attributed to him or her any of the qualities above delineated by the Massachusetts statute.

Professor Gray and Mr. Foulke are not in accord as to the case in which the doctrine originated, but they are agreed as to its origin in Pennsylvania, ${ }^{49}$

17 Mass. Gen. Laws I92I, c. 4, \$ 7 (86).

${ }^{23}$ Wagner v. Wagner, 244 Ill. Ior, 9I N. E. 66 (19ro).

10 Gray, Restraints on Alienation (2d ed. I895) 214 et seq. and Preface viii; Foulke, The Rules Agatnst Perpetuities, Restraints on Alienation and Restraints on ENjoyment As Applicable to Gifts of Property in PeNnsylvania (ig09) .267-268, 291-294. 
and in spite of the strictures of them both upon the doctrine, it has almost filled the land. Professor Gray ${ }^{50}$ considers its spread as a reaction against the laissez faire doctrines held in the early part of our existence as an independent nation, but from the standpoint of a settlor entrusting his property to a trustee, to be held for the benefit of a third person, it might be rather held to be an illustration of the laissez faire doctrine itself, since it is grounded on a man's right to do what he will with his own, and to stipulate the terms on which another should enjoy it. Spendthrift trusts were not good originally in Alabama, Kentucky, North Carolina, Rhode Island, South Carolina and Virginia, which held to the English rule that, excepting in the case of trusts for sole and separate use, "the necessary incidents of beneficial ownership in property are liability to creditors and the power of alienation"; 51 but two of these states (i.e., Alabama and Kentucky) have come into line by the simple expedient of having deeds or wills drafted with provisions that, if the income is threatened by attachment or otherwise, the beneficiary should immediately be someone else, who might even be a very near relative of the original cestui que trust, and thus feel morally bound to maintain him, and in that form the deeds or wills are let alone, for a creditor knows that in no event can he get anything. ${ }^{52}$ In no event, however, must the documents give the original cestui que trust any incidents that usually go with absolute ownership, otherwise it will be held to make it liable for creditors' claims. ${ }^{53}$ The other three states mentioned, viz., North Carolina, Rhode Island and Virginia, still hold to their original views, strictly construing any enabling statutes. ${ }^{54}$ But in the remaining states, as the question has been presented, and in the Federal courts, the doctrine seems to have found ready acceptance.

The statutory limitations on the "spendthrift trust" may be summarized briefly. In California, Michigan, Minnesota, Montana, New York, North Dakota, Oklahoma, South Dakota and Wisconsin, statutes, substantially similar, have been enacted which provide that "Whenever an express trust is created to receive the rents and profits of lands, and no valid direction for accumulation is given, the surplus of such rents and profits, beyond the sum necessary for the education and support of the person for whose benefit the

${ }^{c} \mathrm{GRAY}$, op. cit. supra note 49.

" Shelton v. King, 229 U. S. 90, 96, 33 Sup. Ct. 686, 688 (rg12).

${ }^{62}$ This can be best illustrated by citing, in each of these states, a late case, and then comparing it with an early case which held the contrary view. Alabama, Hartwell v. Mobile Towing and Wrecking Co., 2I2 Ala. 3I3, I02 So. 450 (I924) ; cf. Jones v. Reese, 65 Ala. I34 (1880); Bottom v. Fultz, I24 Ky. 302, 98 S. W. 1037 (1907); cf. Parsons v. Spencer, 83 Ky. 305 ( 1885 ), the later case also involving a new state statute.

${ }^{2}$ Compare the following South Carolina cases: Heath v. Bishop, 4 Rich. Eq. 46 (I85I) ; Symmes v. Cauble, 85 S. C. 435,67 S. E. 548 (I909) ; Spann v. Corson, I23 S. C. 37I, II6 S. E. 427 (1922). See also infra note 77.

" North Carolina, Bank v. Heath, I87 N. C. 54, I2I S. E. 24 (I924) ; Rhode Island, In re Petition of Smyth, 49 R. I. 62, I39 Atl. 657 (1927), reaffirming their old case of Tillinghast v. Bradford, 5 R. I. 205 (I858) ; Virginia, Hutchinson v. Maxwell, I00 Va. 169, 40 S. E. 655 (1902); Honaker v. Duff, 10I Va. 675, 44 S. E. 900 (I903), and Dunlop v. Dunlop, I44 Va. 297, I32 S. E. 35I (I926). 
trust is created, shall be subject in equity to the claims of his creditors, in the same manner as other personal property which cannot be reached by an execution at law." 55 Arizona pernits such a trust if created by a father or mother and for the benefit of a child or children, but a court can dissolve it. ${ }^{\overline{5}}$

In Connecticut, it is provided that "whenever property is given to trustees to pay over the income to any person, and there is no provision for accumulation, and the trustees are not expressly authorized to withhold such income, and the income is not expressly given for the support of the beneficiary or his family, such income shall be liable in equity to the claims of all creditors of such beneficiary", ${ }^{57}$ but the statute contains so many exceptions that courts have nad no difficulty in holding that if the trustees have the discretion to accumulate income, creditors cannot reach it, so that their rights can be easily nullified. ${ }^{\text {s }}$ In Delaware, the only law on the subject is a dictum of fifty years ago that spendthrift trusts are valid only for the maintenance of the beneficiary. 50 In Georgia, such trusts are only valid for a minor or a person non compos mentis, or "any male person of age whenever in fact such person is, on account of mental weakness, intemperate habits, wasteful and profligate habits, unfit to be entrusted with the right and management of property", thus confining its application substantially to the definition of the spendthrift above given in Massachusetts, and the deed must be recorded and the court can, on petition and proof to the contrary, dissolve the trust created for these spendthrifts. ${ }^{60}$ This provision only applies to males of intemperate habits, as apparently Southern chivalry could not contemplate the possibility of an intemperate female. ${ }^{61}$ In New Jersey, the statute allows an execution against a spendthrift trust "provided the income of such trust property shall exceed $\$ 4000^{\prime \prime}{ }^{62}$ but the validity of such a trust is still open to some question. ${ }^{63}$ North Carolina permits anyone "by deed or will to convey any property, which does not yield at the time of the conveyance a clear annual income

${ }^{\circ}$ Cal. Civ. Code (Deering, I923) §859; Mich. Comp. Laws (Cahill, I915) \& II577; Minn. Stat. (Mason, I927) \&8092; Mont. Rev. Codes (Choate, I921) \&6788; N. Y. Cons. Laws (Cahill, 1930) N. Y. Real Property Law (1909) \& 98; McKininey, Cons. Laws, vol. 49 , re-enacting a provision established in I828, I R. S. (I836) 723, Uses and Trusts $\$ 57$; (applied also to personal property) Williams v. Thorn, $70 \mathrm{~N}$. Y. 270 (I877) ; amendment of I908, N. Y. Laws I908, c. 148, construed in Brearley School v. Ward, 201 N. Y. 358, 94 N. E. IOOI (I9II), aff'g I38 App. Div. 833, I23 N. Y. Supp. 614 (1910); N. D. CoMp. LAwS ANN. (1913) \$ 5369; OKLA. Rev. Laws (I921) \$8470; S. D. Rev. Code (1929) \$376; WIS. Stat. (I927) \$23I.I3.

${ }^{60}$ Ariz. Rev. Code (Struckmyer, I928) § 3647 .

${ }^{57}$ Conn. Gen. Stat. (Rev. I930) $\$ 5723$.

¿ Foley v. Hastings, IO7 Conn. 9, I39 At1. I05 (1927); cf. Carter v, Brownell, 95 Conn. 2I6, III Atl. I82 (I920).

${ }^{t}$ Gray v. Corbitt, 4 Del. Ch. 135 (1871).

${ }^{\infty}$ GA. ANv. CODE (Michie, 1926), § 3729.

- See Gray v. Obear, $54 \mathrm{Ga}$. 23I (1875).

N. J. Comp. Stat. (1910) 2254, § 300.

( L'Hommedieu v. L'Hommedieu, g8 N. J. Eq. 554, I3I Atl. 302 (1925), and cases therein cited. 
exceeding $\$ 500$, to any other person in trust to receive and pay the profits annually or oftener for the support and maintenance of any child, grandchild or other relation of the grantor, for the life of such child, grandchild or other relation, with remainder as the grantor shall provide". ${ }^{64}$ Virginia allows it for any estate "not exceeding $\$ 100,000$ in actual value . . . but no such trust shall operate to the prejudice of any existing creditor of the creator of such trust." 65 West Virginia has, by a recent statute, adopted a substantially similar provision to the Delaware dictum, which relieves from the claims of creditors, trusts to be applied "to the support and maintenance of a beneficiary . . . in being at the time of the creation of the trust, for the life of such beneficiary." 66 This statute, as do many of the others, exempts from its protective provisions trusts created by settlors for their own benefit, an exception which would probably have been made in any event, and which was denounced in Pennsylvania seventy-five years ago ${ }^{67}$ as violating the Statute of I 3 Elizabeth.

New York, as has been previously indicated, started out with a statute permitting spendthrift trusts for education and support only, ${ }^{68}$ and this led to several judicial pronouncements, which have been severely criticised, as to what was a proper measure of support for people who had been brought up with leisure and expensive tastes. The cases have been reviewed in an able article in a leading law review, and so need not be touched on here. ${ }^{69}$ Finally a statute was passed in New York, providing that where the income of the beneficiary of a trust amounts to $\$ I 2$ a week or more, it may be reached by any judgment creditor of the beneficiary by a special form of execution, to the extent of ten per cent. of such income. ${ }^{70}$ And as the Federal courts have recently decided that in a bill against a trustee service may be made by publication under the United States statutes, creditors may in that state now have a remedy which should prove really effective. ${ }^{71}$

Finally, there are two states which by statute refuse to uphold spendthrift trusts against certain classes of persons. The first is Missouri, which provides that "restraints upon the right of the cestui que trust to alienate or anticipate the income.. . and all attempts to withdraw said income of any trust estate from the claims of creditors of the cestui que trust, whether

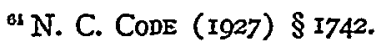

$\approx$ VA. CODE ANN. (1924) §5157.

${ }^{\infty}$ W. VA. OfFTCIAL CODE (I93I) c. 36 , art. I, § I8.

${ }^{6}$ Mackason's Appeal, $42 \mathrm{~Pa} .330$ (1862), and cases therein menticned and which has been often cited since.

${ }^{\infty}$ Sitpra note 55.

${ }^{\infty}$ Griswold, Reaching the Interest of the Beneficiary of a Spendthrift Trust (1929) 43 HARv. L. REv. 63, which was followed by an article by the same author, Spendthrift Trusts Created in Whole or in Part for the Benefit of the Settlor (I930) 44 HARv. L. REv. 203.

To N. Y. Crv. Prac. ACT (Cahill, r925) §684; N. Y. CoDE CIv. PRoc. § I39I ; N. Y. Laws Ig03, c. $46 \mathrm{I}$ as amended by N. Y. Laws I908, c. I48; cited supra note 55 .

${ }^{7}$ Spellman v. Sullivan, 43 F. (2d) 762 (S. D. N. Y. I930). 
said restraints be by will or deed, now existing or in force, or, which may be hereafter executed in this state, be and the same are hereby declared null and void and of no effect, as against the claims of any wife, child or children, of said cestui que trust for support and maintenance, or, as against the claim of any said wife for alimony." 72 The second and last state is Pennsylvania, the home of the spendthrift trust, which finally found that its rules applied in strictness were allowing people to create such trusts at the expense of the state itself, ${ }^{73}$ and passed a statute in 1913 which was amended in 1917 , and was followed by a more comprehensive Act in I92I which provided that, under court order, fifty per cent. of the income of a spendthrift trust was liable for the support and maintenance of the wife and minor children of the beneficiary and for the value of necessaries furnished to them or any of them where said beneficiary has refused or neglected to provide suitably for them. ${ }^{\text {i4 }}$ And the last Act, which was retroactive, has been held constitutional but construed as to cover only citizens who might become a public charge. ${ }^{75}$ The causes of these various statutes in the nineteen states enumerated were twofold: first, the desire to relieve the state of the possible obligation of caring for certain people likely to become public charges, when there was income that could be made primarily responsible for necessities furnished them; and secondly, the desire to protect people who had extended to beneficiaries of spendthrift trusts credits based on their scale of living and apparent means, since their creditors generally lacked other ways of getting knowledge of their financial responsibility, as most deeds of trust are unrecorded, and the names of beneficiaries under wills-and especially if they are married women-often afford no clue to the name of the testator whose estate may be supporting them.

The reading of the American spendthrift trust cases-about a hundred, outside of the group in Pennsylvania-affords glimpses of skeletons in many family closets which conflicting interests have forced into the blazing light of court proceedings. The domestic trials and tragedies therein delineated or briefly outlined are only surpassed in intensity by the rapidly increasing list of decisions involving dispositions of property made or claimed to have

72 Mo. Rev. Stat. (I9I9) §55\%.

${ }^{73}$ Thackara v. Mintzer, I00 Pa. I5I (I882) and Board of Charities v. Lockard, I98 Pa, 572, 48 Atl. 496 (IgOI).

${ }^{74}$ Acts of Apr. 15, 1913, P. L. 72; June 7, 1917, P. L. 409, § 19; June 15, 1917, P. L. 614; May IO, I92I, P. L. 434. In the I93I session of the Pennsylvania legislature a bill was introduced ( $\mathrm{H}$. B. 893) to make all spendthrift trusts subject to execution and attachment stir judgment, sequestration or other process, and the spendthrift trust provision void as against any creditors of the beneficiary; but this bill was never reported out by the Committee on Judiciary General. The texts of the above statutes, and a review of the recent decisions in this state on spendthrift trusts have been collected in Note (193I) 5 TeMrle L. Q. 626, so further comment on the recent Pennsylvania cases is unnecessary. 1930).

${ }^{75}$ Everhart v. Everhart, 8z Pa. Super. I84 (I926) ; Smith's Est., I3 D. \& C. 508 (Pa. 
been made in contemplation of death . . . tragic dramas in real life, in which the two grim inevitables, death and taxes, play the leading roles.

There are many curious cases. Some of the early ones in the South are based on the social structure which became extinct with the Civil War. Thus an Alabama case in 1846 sustained the bequest of certain slaves under a spendthrift trust for the benefit of the testator's son and his family during the son's life $;^{76}$ but in a South Carolina case in 1858 , where certain named negroes who could not be removed from the state were put under a somewhat similar spendthrift trust, it was held that a creditor could sequester them by an equity suit-a novel application of the maxim that equity acts in personam. $^{\top 7}$ In New Hampshire a court was finally prevailed on to fix a maximum and a minimum within which a timorous trustee could function without risking a petition for his removal on the ground of his unreasonableness. ${ }^{i 8}$ And as the converse of the cases which provide that the income shall not be subject to attachment for the debts of the cestui que trust, we find cases where the trustee can pay over the principal when satisfied that the cestui que trust is free from debt or when he has behaved himself properly for a specified period. $^{79}$ But the trustee cannot act arbitrarily or without a reasonably searching investigation of the true facts. ${ }^{\text {so }}$

The psychologists have not yet studied the problem and charted definite conclusions, but it is probably true that there is a certain loosening of the moral fiber that ultimately affects the beneficiaries of a spendthrift trust and impairs both their civic value and general efficiency; and this deteriorating tendency is in all likelihood passed down in increasing measure to their descendants similarly protected. We sympathize with the indignant remonstrance of Chief Justice Ames, of Rhode Island, in 1858 , in Tillinghast $v$. Bradford, "Certainly, no man sinould have an estate to live on, but not an estate to pay his debts with. Certainly, property available for the purposes of pleasure or profit, should be also amenable to the demands of justice."

In line with what has been said, we may cite the following from the opinion of Chief Justice Wilson of Minnesota in the Congdon case: ${ }^{82}$

"The human race may well profit by using the busy honey-bee as an example. The drone is held in little respect. No policy should be adopted that would tend to make us a nation of drones. Idleness is the

${ }^{78}$ Rugely v. Robinson, Io Ala. 702 (1846).

$\pi$ Wylie v. White, Io Rich. Eq. 294 (S. C. I853).

Eaton v. Eaton, 82 N. H. 216, I32 Atl. 1o (1926); cf.' Eaton v. Lovering, 8I N. H. 275, I25 At1. 433 (I924).

${ }_{70}$ Brownson v. Gifford, 8 How. Pr. 389 (N. Y. I852) ; Dunephant v. Dickson, 153 Mo. App. 309, 133 S. W. I65 (1910); Eberly's App., I10 Pa. 95, I Atl. 330 (1885); First National Bank of Nashville v. Nashville Trust Co., 62 S. W. 392 (Tenn. Ch. App. Igor).

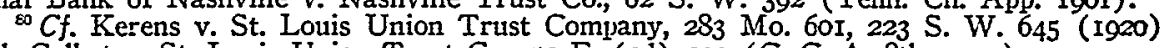
with Colket v. St. Louis Union Trust Co., 52 F. (2d) 390 (C. C. A. 8th, I93I).

${ }^{8}$ Supra note 54 , at 212 .

$\approx$ Congdon v. Congdon, supra note $2 \mathrm{~T}$, at $365,200 \mathrm{~N}$. W. at 83 . 
father of moral delinquency. . . . It is better to adopt that policy that leads the citizen to vigilance and labor, . . . It is best that the rash of ambition may develop on any citizen. . . . Our policy is to guard against the creation of an aristocracy and to compel every individual in a measure to accumulate, and, at least, to sustain his fortune by the strength of his individual superiority and ability, and to avoid an artificial inequality of persons or a deterioration of character. The tendency of restriction is to say that there is no objection to an individual receiving a large fortune by way of gift provided he has unfettered control of it. The theory of restriction is that the recipient should be made to take a 'sporting chance' on his ability to keep it, without depending upon the prerogative of the dead. Responsibility develops both manhood and citizenship."

In the long run, a man's good name is best handed down by the quality of his descendants rather than by their quantity or the size of their bank accounts, however desirable the two latter may also be. And if that is so, then in successive generations, all protected by spendthrift trusts, the trusts defeat their own ends, for the law of the survival of the fittest to survive applies to families as well as to individuals. 